\title{
Effects of Different Retail Packaging Materials on the Shelflife of Dehusked Foxtail Millet
}

\author{
Pooran Pragnya*, Ravi Kumar, P.F. Mathad and Vikas Jha \\ College of Agricultural Engineering, Raichur, Karnataka, India \\ *Corresponding author
}

A B S T R A C T

\begin{tabular}{|c|c|}
\hline & \multirow{6}{*}{$\begin{array}{l}\text { Millets are in the family of cereals grown globally with differential importance across } \\
\text { continents and within regions of the world. Cereals are staple foods for a large proportion } \\
\text { of the world population. The present investigation was carried out to find out the effect of } \\
\text { different retail packaging material on the shelf-life of dehusked foxtail millet. The foxtail } \\
\text { millet was procured at local Raichur market. Physical properties of dehusked foxtail millet } \\
\text { viz., particle density, bulk density, angle of repose, coefficient of internal friction, } \\
\text { coefficient of external friction, length, breadth, thickness, size and spherecity were found } \\
\text { to be } 1.34 \mathrm{~g} / \mathrm{cc}, 0.87 \mathrm{~g} / \mathrm{cc}, 27.26^{\circ}, 0.34,0.27,2.02 \mathrm{~mm}, 1.28 \mathrm{~mm}, 1.12 \mathrm{~mm}, 1.43 \mathrm{~mm} \text { and } \\
70.78 \% \text { respectively. Biochemical properties of dehusked foxtail millet viz., fat, fibre } \\
\text { carbohydrate, ash, protein, moisture content were determined initially to be } 5.68 \% \text {, } 4.76 \\
\%, 64.77 \%, 1.64 \%, 13.80 \% \text { and } 9.35 \% \text {, respectively and there was no insect infestation } \\
\text { before storing the commodity. Three types of packaging materials were used for retail } \\
\text { packaging ( } 1 \mathrm{~kg} \text { ) namely polyethylene (PE), polypropylene (PP) and polyethylene } \\
\text { terapthalate (PET). The dehusked foxtail millet packed in different packaging material was } \\
\text { kept for storage studies for } 6 \text { months. Quality analysis and insect infestation were checkeed } \\
\text { regularly at the interval of } 1 \text { month. Finally it was concluded that for retail packaging PET } \\
\text { was found to be best, based on its improved quality parameters and minimized insect } \\
\text { infestation and also to prevent the damages due to insects and nutrient losses. }\end{array}$} \\
\hline & \\
\hline $\begin{array}{l}\text { Foxtail millet, } \\
\text { Physical properties, } \\
\text { Biological properties } \\
\text { and insect infestation }\end{array}$ & \\
\hline Article Info & \\
\hline $\begin{array}{l}\text { Accepted: } \\
16 \text { April } 2018 \\
\text { Available Online: } \\
10 \text { May } 2018\end{array}$ & \\
\hline & \\
\hline
\end{tabular}

\section{Introduction}

Millets are in the family of cereals grown globally with differential importance across continents and within regions of the world. Cereals are staple foods for a large proportion of the world population. Cereal grains contribute a significant amount of energy, protein, selected micronutrients and nonnutrients in the diet of populations all over the world in both developed and developing countries. Cereal and cereal-based food products provide more than $56 \%$ of the energy and $50 \%$ of the protein consumed worldwide. Economically important cereals in the world are maize, rice, wheat, barley, sorghum, millets, oat and rye (Shahidi and Chandrasekara, 2013).

India stands $2^{\text {nd }}$ position in total world production of millet (Deshpande and Poshadri, 2011). In India total production of foxtail millet is 125 MT (2011-12) (www.indexmundi.com). In Karnataka, small 
millets are cultivated on an area of 1.25 Mha producing 1.54 MT with a productivity of $1230 \mathrm{~kg} / \mathrm{ha}$. Nutritional values of foxtail millet (Setaria italica) per $100 \mathrm{~g}$ of edible portion contains, water $12.5 \mathrm{~g}$, protein $12.3 \mathrm{~g}$, lipid 4.3 $\mathrm{g}$, carbohydrate $60.1 \mathrm{~g}$, ash $1.2 \mathrm{~g}$, fat $4.3 \mathrm{~g}$, dietary fiber $9.0 \mathrm{~g}$, calcium $3.1 \mathrm{~g}$, minerals 3.3 $\mathrm{g}$, vitamins and thiamine $590 \mathrm{mg}$. Minor millets are fair sources of protein and are limiting in lysine (Malleshi and Desikachar, 1985). Storage of crops is an essential component of the whole production system.

It facilitates several farmer objectives, namely, availing food for the future and avoiding food shortage, providing seed during the next growing season, allows the farmer to sell at a time when the price is good. Recently it has been reported, $9 \%$ post-harvest losses, due to insects and mite infestation worldwide, suggesting a need to make an overall effort to control these post-harvest losses. The most conservative estimate for post-harvest losses in food grains in India even put at about $10 \%$, a quantity good enough to feed at least 60 million people. Therefore considering these problems rose in processed millets and to increase its shelf life, the study conducted to enhancing the shelf life of dehusked foxtail millet with the following objectives:

To study the Physical and biochemical properties of foxtail millet

To evaluate the Shelf life of dehusked foxtail millets using different retail packaging materials.

\section{Materials and Methods}

\section{Raw material}

The experiment was conducted in the Department of Processing and Food Engineering, College of Agricultural Engineering, Raichur, Karnataka. Raichur is situated on the latitude of $16^{\circ} 15^{\prime}$ North, longitude of $77^{\circ} 21^{\prime}$ East and at an elevation of 389 meters above mean sea level which is considered as North Eastern Dry Zone of Karnataka.

The raw material such as foxtail millet (variety: H-1) was procured from Raichur local market. Before packaging foxtail millets were cleaned, dried at room temperature $\left(30 \pm 2{ }^{\circ} \mathrm{C}\right)$ till it reaches 10 per cent moisture content and dehusked using Millet dehusker and packed in different retail packaging materials such as Polyethylene (PE), Polypropylene (PP), Polyethylene terapthalate (PET) and kept for storage studies for 6 months.

\section{Physical properties of foxtail millet}

The physical properties of the millets are important in designing particular equipment or determining the behaviour of the product for its handling. The methodology followed for various physical properties of the foxtail millet are discussed hereunder.

\section{Proximate composition of foxtail millet}

The proximate composition viz., moisture content, crude fibre, crude fat, total ash/mineral content, crude protein and carbohydrates of foxtail millet were estimated by following the standard methods

\section{Insect infestation of foxtail millet}

\section{Weeviled and germ eaten grain counting method}

Grain sample of $50 \mathrm{~g}$ was taken, from which a 100 number of grains were drawn randomly. Weeviled grains and germ eaten grains were separated from the sample and are counted to determine the percent mass loss using following formula. 
Mass loss $(\%)=\frac{(\mathrm{W}+\mathrm{G})-100}{\mathrm{~S}\left(\mathrm{~W}_{1}+\mathrm{G}_{1}\right)} \times 100$

Where,

$\mathrm{W}=$ Percentage by number of weeviled grains

$\mathrm{G}=$ Percentage by number of germ eaten grains

$\mathrm{W}_{1}=$ Mass of $\mathrm{W}$ grains (in grains)

$\mathrm{G}_{1}=$ Mass of $\mathrm{G}$ grains (in grams)

$\mathrm{S}=$ Mass of 100 healthy grains

This method lays stress on the nature of the damage so distinction has to be made between weeviled and germ eaten grains among the damaged grains due to insect pests. This method first involves the separate set of hundred counting of two types of damaged grains and then again counting a separate set of hundred healthy grains for ultimately arriving at mass loss due to insects pests. This method hence is preferred where pest complex causing the different nature of damages is causing infestation to the grains. However, mass loss due to weeviled grains and germ eaten grains cannot be estimated separately by this method.

\section{Results and Discussion}

This chapter deals with the results obtained for various physical and biochemical properties of dehusked foxtail millet and it also includes the results of experiment conducted to investigate the effect of different retail packaging materials on shelf-life of dehusked foxtail millet.

\section{Physical properties of dehusked foxtail millet}

The mean values of physical properties of unhusked and dehusked foxtail millet viz., Particle density, Bulk density, Angle of repose, Coefficient of internal friction, Coefficient of external friction, Length,
Breadth, Thickness, size and Spherecity were determined using different standard methods. The data obtained for physical properties of uhusked and dehusked foxtail millet are presented in Table 1 it is inferred that the average particle density of $1.34 \mathrm{~g} / \mathrm{cc}$, bulk density of $0.87 \mathrm{~g} / \mathrm{cc}$, angle of repose of $27.26^{\circ}$, coefficient of internal friction of 0.34 , coefficient of external friction of 0.27 , length of $2.02 \mathrm{~mm}$, breadth of $1.28 \mathrm{~mm}$, thickness of $1.12 \mathrm{~mm}$, size of $1.43 \mathrm{~mm}$ and spherecity of $70.78 \%$ was recorded for dehusked foxtail millet. It was also observed that the average particle density of $1.26 \mathrm{~g} / \mathrm{cc}$, bulk density of $0.77 \mathrm{~g} / \mathrm{cc}$, angle of repose of $27.03^{\circ}$, coefficient of internal friction of 0.48 , coefficient of external friction of 0.40 , length of $2.16 \mathrm{~mm}$, breadth of $1.31 \mathrm{~mm}$, thickness of $1.31 \mathrm{~mm}$, size of $1.49 \mathrm{~mm}$ and spherecity of $68.60 \%$ was also recorded for unhusked foxtail millet. A similar finding was reported by Subramanian and Viswanathan (2007)

\section{Biochemical properties of dehusked foxtail millet}

The mean values of biochemical properties of unhusked and dehusked foxtail millet viz., moisture content (\% wet basis), moisture content (\% dry basis), protein content (\% db), fat content $(\% \mathrm{db})$, ash content $(\% \mathrm{db})$, fibre content $(\% \mathrm{db})$, carbohydrate content and insect infestation were determined using different standard methods. The data obtained for biochemical properties of uhusked and dehusked foxtail millet are presented in Table 2 , it is inferred that the average moisture content on wb) of $(9.35 \%)$, moisture content (on $\mathrm{db}$ ) of $(10.31 \%)$, protein content of (13.44 $\%)$, fat content of $(5.37 \%)$, ash content of $(1.53 \%)$, fibre content of $(4.76 \%)$ and carbohydrate content of $(64.90 \%)$ were recorded for dehusked foxtail millet. It was also inferred that average moisture content (on wb) of $(9.46 \%)$, moisture content (on db) of $(10.45 \%)$, protein content of $(12.86 \%)$, fat 
content of (4.20\%), ash content of (3.20\%), fibre content of $(6.68 \%)$ and carbohydrate content of $(63.18 \%)$ were recorded for unhusked foxtail millet.

Moisture content of dehusked foxtail millet stored in different retail packaging materials (\% wet basis)

The moisture content of dehusked foxtail millet packed in 3 different retail (1 kilo gram) packaging materials and stored at ambient condition for 6 months are recorded and presented in the Table 3 .

From the table it is observed that the moisture content of millet decreased from 9.35 to 7.55 in PE, 9.35 to 7.77 in PP and 9.35 to 8.51 in PET, respectively

Protein content of dehusked foxtail millet stored in different retail packaging materials (\% db)

The effect of storage on protein content of dehusked foxtail millet stored in different packaging materials are shown in the Table 4. Irrespective of type of packages, generally there was a marginal decrease in protein content of millets after 6 months of storage. The range of reduction in protein content was from $13.80 \%$ to $12.78 \%$ in PE, $13.80 \%$ to $12.91 \%$ in PP and $13.80 \%$ to $13.23 \%$ in PET.

Fat content of dehusked foxtail millet stored in different retail packaging materials (\% db)

The effect of storage on Fat content of dehusked foxtail millet stored in different packaging material is shown in the Table 5. From the table it is observed that there was a marginal decrease in fat content of millets after 6 months of storage irrespective of type of packaging material. The range of reduction in fat content was from $5.68 \%$ to $5.05 \%$ in PE, $5.68 \%$ to $5.15 \%$ in PP and $5.68 \%$ to $5.37 \%$ in PET.

Ash content of dehusked foxtail millet in different retail packaging materials $(\% \mathrm{db})$

The effect of storage on ash content of dehusked foxtail millet stored in different packaging material is shown in the Table 6 . Irrespective of type of packages, generally there was a marginal increase in ash content of millets after 6 months of storage. The range of increase in Ash content was from $1.64 \%$ to $1.91 \%$ in PE, $1.64 \%$ to $1.87 \%$ in PP and $1.64 \%$ to $1.90 \%$ in PET.

Table.1 Physical properties of dehusked foxtail millet

\begin{tabular}{|c|c|c|c|}
\hline SI. No. & Physical property & $\begin{array}{c}\text { Unhusked foxtail } \\
\text { milllet }\end{array}$ & $\begin{array}{c}\text { Dehusked Foxtail } \\
\text { millet }\end{array}$ \\
\hline $\mathbf{1}$ & Particle density & $1.26 \mathrm{~g} / \mathrm{cc}$ & $1.34 \mathrm{~g} / \mathrm{cc}$ \\
\hline $\mathbf{2}$ & Bulk density & $0.77 \mathrm{~g} / \mathrm{cc}$ & $0.87 \mathrm{~g} / \mathrm{cc}$ \\
\hline $\mathbf{3}$ & Angle of repose & $27.03^{0}$ & $27.26^{\circ}$ \\
\hline $\mathbf{4}$ & Coefficient of internal friction & 0.48 & 0.34 \\
\hline $\mathbf{5}$ & Coefficient of external friction & 0.40 & 0.27 \\
\hline $\mathbf{6}$ & Length & $2.16 \mathrm{~mm}$ & $2.02 \mathrm{~mm}$ \\
\hline $\mathbf{7}$ & Breadth & $1.31 \mathrm{~mm}$ & $1.28 \mathrm{~mm}$ \\
\hline $\mathbf{8}$ & Thickness & $1.31 \mathrm{~mm}$ & $1.12 \mathrm{~mm}$ \\
\hline $\mathbf{9}$ & Size & $1.49 \mathrm{~mm}$ & $1.43 \mathrm{~mm}$ \\
\hline $\mathbf{1 0}$ & Spherecity & $68.60 \%$ & $70.78 \%$ \\
\hline
\end{tabular}


Table.2 Biochemical properties of dehusked foxtail millet

\begin{tabular}{|c|c|c|c|}
\hline sl.no & Biological property & $\begin{array}{c}\text { Unhusked foxtail } \\
\text { millet }(\%)\end{array}$ & $\begin{array}{c}\text { Dehusked Foxtail } \\
\text { millet (\%) }\end{array}$ \\
\hline $\mathbf{1}$ & Moisture content $(\% \mathrm{wb})$ & 9.46 & 9.35 \\
\hline 2 & Moisture content $(\% \mathrm{db})$ & 10.45 & 10.31 \\
\hline 3 & Protein & 12.86 & 13.80 \\
\hline 4 & Fat & 4.2 & 5.68 \\
\hline 5 & Ash & 3.2 & 1.64 \\
\hline 6 & Fibre & 6.68 & 4.76 \\
\hline 7 & Carbohydrates & 63.18 & 64.77 \\
\hline
\end{tabular}

Table.3 Moisture content of dehusked foxtail millet (\% wet basis)

\begin{tabular}{|c|c|c|c|c|c|c|c|}
\hline $\begin{array}{c}\text { Packaging } \\
\text { Material }\end{array}$ & \multicolumn{7}{|c|}{ Month } \\
\hline PE & 9 & 1 & 2 & 3 & 4 & 5 & 6 \\
\hline PP & 9.35 & 9.26 & 9.19 & 8.78 & 8.37 & 7.87 & 7.55 \\
\hline PET & 9.35 & 9.27 & 8.97 & 8.67 & 8.37 & 8.07 & 7.77 \\
\hline
\end{tabular}

Table.4 Protein content of dehusked foxtail millet (\% db)

\begin{tabular}{|c|c|c|c|c|c|c|c|}
\hline $\begin{array}{c}\text { Packaging } \\
\text { Material }\end{array}$ & 0 & 1 & 2 & 3 & 4 & 5 & 6 \\
\hline PE & 13.80 & 13.57 & 13.41 & 13.25 & 13.09 & 12.91 & 12.78 \\
\hline PP & 13.80 & 13.54 & 13.42 & 13.18 & 13.18 & 13.02 & 12.91 \\
\hline PET & 13.80 & 13.78 & 13.58 & 13.49 & 13.42 & 13.29 & 13.23 \\
\hline
\end{tabular}

Table.5 Fat content of dehusked foxtail millet (\% db)

\begin{tabular}{|c|c|c|c|c|c|c|c|}
\hline $\begin{array}{c}\text { Packaging } \\
\text { Material }\end{array}$ & 0 & 1 & 2 & 3 & 4 & 5 & 6 \\
\hline PE & 5.68 & 5.35 & 5.29 & 5.23 & 5.17 & 5.11 & 5.05 \\
\hline PP & 5.68 & 5.38 & 5.33 & 5.26 & 5.23 & 5.18 & 5.15 \\
\hline PET & 5.68 & 5.62 & 5.57 & 5.53 & 5.47 & 5.42 & 5.37 \\
\hline
\end{tabular}

Table.6 Ash content of dehusked foxtail millet (\% db)

\begin{tabular}{|c|c|c|c|c|c|c|c|}
\hline $\begin{array}{c}\text { Packaging } \\
\text { Material }\end{array}$ & \multicolumn{9}{|c|}{ Month } \\
\hline PE & 1.64 & 1 & 2 & 3 & 4 & 5 & 6 \\
\hline PP & 1.64 & 1.67 & 1.74 & 1.78 & 1.83 & 1.88 & 1.91 \\
\hline PET & 1.64 & 1.67 & 1.72 & 1.77 & 1.81 & 1.87 & 1.90 \\
\hline
\end{tabular}


Table.7 Fibre content of dehusked foxtail millet (\% db)

\begin{tabular}{|c|c|c|c|c|c|c|c|}
\hline $\begin{array}{c}\text { Packaging } \\
\text { Material }\end{array}$ & \multicolumn{7}{|c|}{ Month } \\
\hline PE & 4 & 1 & 2 & 3 & 4 & 5 & 6 \\
\hline PP & 4.76 & 4.71 & 4.61 & 4.52 & 4.40 & 4.31 & 4.20 \\
\hline PET & 4.76 & 4.62 & 4.54 & 4.45 & 4.38 & 4.30 & 4.23 \\
\hline
\end{tabular}

Table.8 Carbohydrate content of dehusked foxtail millet (in \%)

\begin{tabular}{c|c|c|c|c|c|c|c|}
\hline $\begin{array}{c}\text { Packaging } \\
\text { Material }\end{array}$ & \multicolumn{7}{|c|}{ Month } \\
\hline PE & 0 & 1 & 2 & 3 & 4 & 5 & 6 \\
\hline PP & 64.77 & 65.42 & 65.76 & 66.44 & 67.14 & 67.92 & 68.51 \\
\hline PET & 64.77 & 65.52 & 66.03 & 66.69 & 67.05 & 67.60 & 68.07 \\
\hline
\end{tabular}

Table.9 Insect infestation of dehusked foxtail millet (in \%)

\begin{tabular}{|c|c|c|c|c|c|c|c|}
\hline $\begin{array}{c}\text { Packaging } \\
\text { Material }\end{array}$ & \multicolumn{7}{|c|}{ Month } \\
\hline PE & 0 & 1 & 2 & 3 & 4 & 5 & 6 \\
\hline PP & 0 & 1.96 & 4.33 & 6.80 & 9.49 & 12.40 & 15.70 \\
\hline PET & 0 & 1.70 & 2.80 & 4.10 & 5.65 & 7.40 & 9.40 \\
\hline
\end{tabular}

$\mathrm{PE} \rightarrow$ Poly ethylene

$\mathrm{PP} \rightarrow$ Poly propylene

$\mathrm{PET} \rightarrow$ Polyethylene terephthalate

Physical properties of foxtail millet

\begin{tabular}{|r|r|r|}
\hline S. No. & Physical Properties & Method Used \\
\hline 1 & Specific gravity & Pycnometer method \\
\hline 2 & Angle of repose & Fixed funnel method \\
\hline 3 & Coefficient of external friction & Table provided with changeable surfaces \\
\hline 4 & Coefficient of internal friction & Table provided with changeable surfaces \\
\hline 5 & Bulk density & Kettle method \\
\hline 6 & True density & Displacement Method \\
\hline
\end{tabular}




\section{Proximate composition of foxtail millet}

\begin{tabular}{|c|c|c|}
\hline S1. No. & Chemical properties & Method used \\
\hline 1. & Moisture Content & Hot air oven method \\
\hline 2. & Crude Fibre & $\begin{array}{c}\text { Sequential acid and alkali hydrolysis method (AOAC, } \\
\text { 2005) using Fibra-Plus apparatus }\end{array}$ \\
\hline 3. & Crude Fat & $\begin{array}{c}\text { Soxhlet extraction method (AOAC, 2005) using SOCS } \\
- \text { PLUS apparatus }\end{array}$ \\
\hline 4. & Muffle furnace method \\
\hline 5. & $\begin{array}{c}\text { Total Ash } \\
\text { Crude Protein }\end{array}$ & Micro Kjeltec distillation unit (AOAC, 2005) \\
\hline 6. & Carbohydrates & Anthrone method \\
\hline
\end{tabular}

Fig.1 Graphical representation of insect infestation of dehusked foxtail millet in different retail packaging material

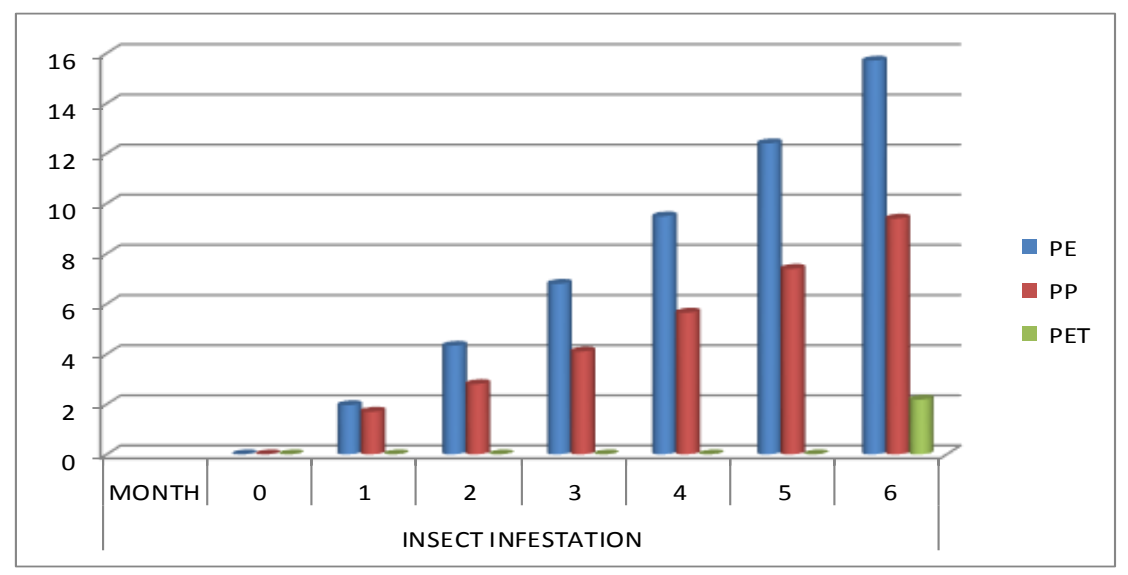

Fiber content of dehusked foxtail millet in different retail packaging materials $(\% \mathrm{db})$

The effect of storage on fibre content of dehusked foxtail millet stored in different packages is shown in the Table 7. Irrespective of type of packages, generally there was a marginal decrease in fibre content of millets after 6 months of storage. The range of reduction in fibre content was from $4.76 \%$ to $4.20 \%$ in PE, $4.76 \%$ to $4.23 \%$ in PP and 4.76 $\%$ to $4.35 \%$ in PET.

Carbohydrate content of dehusked foxtail millet in different retail packaging materials (in \%)

The effect of storage on carbohydrate content of dehusked foxtail millet stored in different packages is shown in the Table 8. From the table it is observed that there was a marginal increase in carbohydrate content of millets after 6 months of storage Irrespective of type of packaging material. The range of increase in Carbohydrate content was from $64.77 \%$ to $68.51 \%$ in PE, $64.77 \%$ to $68.07 \%$ in PP and $64.77 \%$ to $66.64 \%$ in PET. Similar results were observed by Vachanth et al., (2010).

Insect infestation of dehusked foxtail millet stored in different retail packaging materials (in \%)

Insect Infestation is the measure of the grain infested by insect. Tribolium casteneum and Corcyracephalonica was the insect present in the grain. Aspergillus spices were the fungi present in the stored grain. Table 9 indicates 
that PET was least infected whereas PE was the most infected among retail packing materials. PET was $2.18 \%$ infected, PP was $9.40 \%$ and PE was $15.47 \%$ infected during 6 months storage period observed since September (Fig. $1)$.

The present investigation entitled "Studies on enhancing the shelf life of dehusked foxtail millet" was undertaken in the Department of Processing and Food Engineering, College of Agricultural Engineering, University of Agricultural Sciences, Raichur, Karnataka during 2013-14. The results are summarized and the conclusions drawn are presented here under.

Physical properties of dehusked foxtail millet viz., particle density, bulk density, angle of repose, coefficient of internal friction, coefficient of external friction, length, breadth, thickness, size and spherecity were found to be $1.34 \mathrm{~g} / \mathrm{cc}, 0.87 \mathrm{~g} / \mathrm{cc}, 27.26^{\circ}, 0.34,0.27,2.02$ $\mathrm{mm}, 1.28 \mathrm{~mm}, 1.12 \mathrm{~mm}, 1.43 \mathrm{~mm}$ and $70.78 \%$ respectively.

Biochemical properties of dehusked foxtail millet viz., fat, fibre, carbohydrate, ash, protein, moisture content were determined initially to be $5.68 \%, 4.76 \%, 64.77 \%, 1.64 \%, 13.80 \%$ and $9.35 \%$, respectively and there was no insect infestation before storing the commodity.

Three types of packing materials were used for retail packaging $(1 \mathrm{~kg})$ namely $\mathrm{PE}, \mathrm{PP}$ and $\mathrm{PET}$. The dehusked foxtail millet was stored for 6 months in these packaging materials and observations were taken regularly at the interval of 1 month.

It was observed from biochemical properties that the quality of dehusked foxtail millet packed in PET was found to be good as compared to other retail packaging materials and also there was lower insect infestation of about $2.18 \%$. The major conclusion drawn from the present investigation is that for retail packaging PET was found to be best, based on its improved quality parameters and minimized insect infestation and also to prevent the insect infestation and nutrient losses.

\section{References}

AOAC, 2005, Official methods of analysis $\left(16^{\text {th }}\right.$ Edition). Association of official analytical chemists, Washington, DC.

Deshpande, H. W. and Poshadri, A., 2011, Physical and sensory characteristics of extruded snacks prepared from Foxtail millet based composite flours. Int. Food Res. J., 18: 751- 756.

Malleshi, N. G. and Desikachar, H. S. R., 1985, Milling, popping and malting characteristics of some minor millets. J. Food Sci. Technol., 22: 400-403

Sahay, K. M. and Singh, K. K., 2010, Unit operations of agricultural processing. 2nd ed. Vikas Publication, 328-331

Shahidi, F and Chandrasekara, A., 2013, millet grain phenolics and their role in disease risk reduction and health promotion: A review. $\mathrm{J}$. functional foods, 5(2), 570-58.

Subramanian, S and Viswanathan, R., 2007, Bulk density and friction coefficients of selected minor millet grains and flours. J. Food Engg, 81, 118-126.

Vachanth, M. C, Rathinam, K. M, Preethi, R and Loganthan, M., 2010, Controlled atmosphere storage technique for safe storage of processed little millet. Academic Journal of entomology, 3(1): 13-16.

\section{How to cite this article:}

Pooran Pragnya, Ravi Kumar, P.F. Mathad and Vikas Jha. 2018. Effects of Different Retail Packaging Materials on the Shelflife of Dehusked Foxtail Millet. Int.J.Curr.Microbiol.App.Sci. 7(05): 1792-1799. doi: https://doi.org/10.20546/ijcmas.2018.705.210 